\title{
Efforts to prevent conflict and violence in educational institutions
}

\author{
F G Candramukti \\ Islamic Boarding School of Jagad 'Alimussirry \\ Email: febrihadagahascandramukti@gmail.com
}

\begin{abstract}
Every educational institution would want a conducive and peaceful atmosphere in the school environment within the scope of teaching and learning. This does not only apply to certain levels, but almost at various levels of elementary, junior high school, high school and the like. But in the school environment there is still intense conflict and violence, there are several types of conflict and violence in the educational environment which are examined using qualitative descriptive types with the theory of conflict and violence approach, including: Types without conflict, open conflict, surface conflict and conflict. The components of violence are structural violence and cultural violence. Preventive action that should be done is first to socialize the type of punishment for the perpetrators of violence, secondly to design or implement a polite school system.
\end{abstract}

Keywords: Prevention efforts, violent conflict, educational institutions

\section{INTRODUCTION}

Every educational institution or better known as a school, educational institutions would want an atmosphere conducive, calm and peaceful in the teaching-learning process. This is in order to create work stability and the performance of its components. Most important are schools, educational institutions or educational institutions and it is very important to hold a safe and peaceful atmosphere in the school environment [1]. The wishes of the above by each of the educational institutions / schools have been regulated and based on the law no.20 of 2003 [2] concerning the national education system article 1 paragraphs one to three explains, first Education is a conscious and planned effort to create a learning atmosphere and learning process so that students actively develop their potential to have spiritual spiritual strength, self-control, personality, intelligence, noble character, and the skills needed by themselves, society, nation and state. Second, national education is education based on the Pancasila and the 1945 Constitution of the Republic of Indonesia which is rooted in religious values, the national culture of Indonesia and responsive to the demands of changing times. Third, the national education system is an overall component of education that is interrelated in an integrated manner to achieve the goals of national education. Students are regulated in chapter five of article twelve paragraph 2 . Where the starting point explains students must maintain educational norms to ensure the continuity of the process and success of education;

Unlike the case when in schools or educational institutions have not been maximized and consistently apply the mandate of law number 20 of 2003 [2]. In these schools, frequent or ever occurring violent conflicts that arise among school elements. For example, a case of physical violence in the form of a beating of an honorary teacher in high school (SMA) 1 Torjun Sampang in 
2018. The second case of violence, when a teacher pinches a bad student who causes a scar or bruises on his body, in the city of Sidoarjo [3].

Ironically the two incidents of violence that occurred in the educational environment occurred within a period of two years, causing material and psychological losses from the parties concerned [4]. In the case of teacher Budi Sampang's violence, the victim of violence died and caused deep sorrow for his family, especially his wife, who was then pregnant with her first child. In Sidoarjo a teacher named Sambudi teaching in junior high schools (SMP) must be willing to undergo a criminal sentence in the form of prison after getting a decision from the trial process of the Sidoarjo district court in East Java. Both cases are a warning, a reprimand to the government from various parties, be it the public, guardians of students. In fact, both formal and formal educational institutions not only make all students smart with a myriad of achievements, have high learning outcomes, pass national examinations and can be accepted at leading universities.

The occurrence of incidents of violence perpetrated by students against teachers and physical violence of teachers against students is a grim portrait of the world of education about the lack of knowledge relating to typologies of violence and various preventive efforts. Every element of the school should consist of school principals, class teachers, subject teachers, school staff must comprehensively understand the types of conflict-violence religion. The goal is to prevent fictional violence from happening again, like Budi's teacher and a student who become. Based on the background that has been stated, the writer can formulate two main problems that will be used as a compass and discussion guidelines, while the formula is: (1) How is the typology of conflict and violence in the educational institution? (2) What are the efforts to prevent conflict and violence in educational institutions?

\section{METHOD}

This research method uses a qualitative case study approach to conflict and violence using a variety of expert theories of conflict and violence, such as Johan Galtung, Simon Fisher et al as a theoretical foundation and analytical tool. Data on conflict and child violence is obtained from various primary sources namely journals, the results of annual reports from the official website of the Commission for Child Protection (KPAI) and relevant books [5]. There were also results of direct interviews related to Budi's teacher violence with his friends/teacher after the case. At the beginning of the writing in the discussion chapter explains the findings of typology of conflict and violence in general in schools in accordance with the theoretical framework, then provides a comprehensive explanation of the measures to prevent conflict and violence, so that they can be used as input or reference in order to advance and create a world of education that is peaceful and conducive.

\section{RESULT AND DISCUSSION}

Get to know the typology of conflict in the educational environment. We must realize together that the conflict in the educational institution environment continues to occur today, several cases of conflict in educational institutions with varied resolutions, starting from negotiations to criminal ends. At least there have been several cases of conflict in schools from 2016 to 2019. Of the cases that occurred more or less during these four years, can be divided, analyzed according to the typology of conflict according to experts and practitioners of conflict. Conflict, is a relationship between two or more parties (individuals or groups) who have or feel they do not have targets that are not in line [6].

The typology of conflict, first the situation without conflict, surface conflict, latent conflict open conflict. No conflict: A state of peace, security and security, but if the community or members of an educational 
institution want to create a situation that continues and is full of enthusiasm and dynamism, then the community or members of an educational institution must utilize conflicting behavior and goals and manage them creatively. Surface conflict: Has the root of a conflict that is very easily resolved (superficial) not rooted or swollen, adds up. It usually only occurs because of a misunderstanding and can be overcome by negotiation. Open conflict: Having the roots of the conflict is very real and usually requires a variety of responses to overcome the roots and their effects. Latent conflict: The hidden nature of the handling must be raised to the surface, immediately dealt with effectively.

The typology of a situation without conflict in educational institutions occurs when education providers (school principals, teachers, etc.) manage conflicts to be more useful. For example at the high school level (high school) often occurs fights between classes. The organizers of the institution manage these habits into a useful activity, such as a tug of war competition, basketball competition, short and long distance running competitions between classes by involving students who often fight as committee members or participants. The typology of surface conflict can also be seen from some scrutiny as well as being easy to resolve. If the teacher and student have a desire to resolve the conflict, both do not want to be involved too long, then a negotiation is held. Facilitated by the school, experienced and respected teachers. Negotiation activities can be formal or non-formal (not too formal) the most important thing is that there has been a good intention from the conflicting parties.

Third, typology of open conflict. One case like in 2016 happened in Sidoarjo City. When a student's parents report the teacher's actions because the penalty is to pinch one of the students. The settlement of this conflict led to the criminal punishment of the teacher, the mediation process, the negotiation of the school and the families of the students deadlocked. Another case also occurred in my Aliyah boarding school, where the case of eviction of students became an alternative solution. At that time the parents wanted to report the senior santri because he had already carried out physical punishment to his juniors, the wound that left an open root conflict. Last is latent conflict, its nature is hidden, it needs to be raised to the surface so that it is known to the audience, dealt with effectively. One example is the misappropriation of BOS assistance funds by education staff / providers at schools. The distribution of distorted aid funds can lead to protracted conflict between individuals within the school's members. Then the way to resolve it is to bring the conflict to the surface and then settle it according to the agreed agreement. Get to know forms of violence in school

Conflict-violence, these two discussions can occur simultaneously or separately, the difference is in terms of time, type and type. Galtung in his book Peace Studies explains that conflict is a triangle between opposing attitudes, contexts and behavior. While violence is something that can harm and hurt other parties. According to the Criminal Code, article 89 , to commit violence means to use physical force or strength that is not small or as strong as possible, illegally, such as hitting with a hand or with all kinds of weapons, kicking, kicking, and so on, so that people affected by an act feel sick exaggerated. Many cases of violence in educational institutions have been found in the last three years. Data obtained from child protection institutions (LPAI) in 120 cases overall, sadly 94 occurred in the world of education, 20 percent of the perpetrators of people who met each day in the school environment could also work as teachers, educators or teachers. 
Table. I Data of violence during the last three years

\begin{tabular}{ccc}
\hline $\begin{array}{c}\text { Types of } \\
\text { violence }\end{array}$ & Years & violence of school \\
\hline $\begin{array}{c}\text { violence } \\
\text { Direct (physical) } \\
\text { violence }\end{array}$ & 2016 & $\begin{array}{c}\text { A teacher pinches } \\
\text { a student }\end{array}$ \\
\hline $\begin{array}{c}\text { Direct (physical) } \\
\text { violence }\end{array}$ & 2018 & $\begin{array}{c}\text { Student hits his } \\
\text { teacher }\end{array}$ \\
\hline $\begin{array}{c}\text { Direct (physical) } \\
\text { violence }\end{array}$ & 2018 & $\begin{array}{c}\text { The teacher abuses } \\
\text { students }\end{array}$ \\
\hline
\end{tabular}

Source: from KPAI data

Data from the Commission on Child Protection (KPAI) in 2019 states that during the past three years the number of physical violence of children and policy victims was 75 percent. The Indonesian Center for Health and Information [7] explains the impact of violence on children committed under the age of 18 causing negative behaviors, such as smoking, drinking, self-harm, consuming drugs, trying and thinking about committing suicide.

The following is a typology of forms of violence against children in educational institutions based Galtung, [8]: First, direct violence / structural violence is violence that is done directly and has an impact on physical injury, moodiness, trauma, isolation and so forth. Typology of violence can also be in the form of verbal violence such as intimidation/member pressure/ pressure, being ridiculed / mocked, insulted/insulted and bullied, both personally and in groups. Even intimidation, bullying does not only occur face to face, but can also be with cyberspace or better known as cyber bullying. One of the proprietary research Pandori, [9] through FGD (focus group discussion) regarding adolescent perceptions about victims and perpetrators of cyber bullying shows some quite dilemma findings. First, that the conception of joking or joking is the most visible motivation conveyed by students in the FGD. secondly, the joking activity made it possible to become a serious cyber bullying because the victim felt hurt but the majority of the perpetrators did not realize it. Cultural violence can be divided according to content: religion, law, ideology, language, art, empirical-formal science, cosmology. Vulnerable occurs in schools, universities. Examples of cultural violence in the educational environment are punishments that cause students to be exhausted / exhausted, for example giving excessive assignments, giving deadlines for the collection of strict work. The existence of these effects certainly has a negative impact on students' physical and mental development, despite their initial intention to provide good education / teaching [10-11].

Efforts to prevent conflict and violence in educational institutions / schools.

Conflict and violence can't be avoided in social life, especially in educational institutions (schools). This is because of the instinctive nature that each individual has, but at least conflict and violence can be minimized and even eliminated by various management. Then the efforts to prevent conflict and violence must be done by the school institution so that a sense of security and comfort arises. Factors that influence the comfort or climate of this school are relationships or attachments between school members, interaction between school members, mutual trust and respect between school members. The safety, comfort and discipline of a school is determined by the values and attitudes of school residents, including the principal, teachers, students, parents, school committee. In safe schools, school members have a deep commitment in creating and maintaining schools. Incidents of intimidation, violence are resolved quickly, effectively and the restoration of relations between school members is quickly restored.

\section{A. Introduce legal sanctions for school violence}

Introducing or socializing about the existence of penalties or crimes against conflicting parties and perpetrators of violence in schools is very necessary, considering that there are still many members of the school do 
not know the consequences of conflict and violence. The law stipulates that no. 23 of 2002 concerning Child Protection contains criminal sanctions for perpetrators of violence. These criminal provisions are contained in Chapter XII from article 77 to article 90. or According to Article 77 of Law No. 23 of 2002 [12] concerning the protection of children, every person who intentionally acts of discrimination against children that causes children to suffer losses, both material and moral, so that hampering their social functions; and neglect of a child which causes the child to experience illness or suffering, whether physical, mental, or socially liable to a maximum imprisonment of 5 (five) years and / or a maximum fine of Rp 100,000,000.00 (one hundred million rupiah). The socialization of articles or laws concerning cases of violence against children, of course, must be installed in the open space of the school environment, so that it can be read and known thoroughly by each school member. Besides that, teachers, school principals are never bored so that school members obey them.

\section{B. Design and implement a polite school system}

The next effort is to apply a polite school system, the system can consist of several aspects, first developing a positive school culture (greeting each other, greeting). Second, mutual respect and uphold the principle of openness and transparency. Third, the application of rules about good behavior (ethical issues) made for all schools, in partnership with the community in terms of security and school activities.

Furthermore, looking for alternative substitutes for punishment by giving confidence to students to admit their mistakes. Offering the type of punishment that can be done, of course, the punishment can make other students aware of identifying mistakes that are small or large. No less important in applying penalties also involves parents or guardians of students. For example, replacing the penalty of running around the field or drying students in the sun when students are late for a ceremony is replaced with a kind of compassionary punishment, such as asking students to memorize foreign language vocabulary, making workshops in accordance with the theme of the lesson in order to foster student interest in learning and free from the shackles of fear. Refer to the results of integrated research on the empowerment of women and children [13]. A safe, comfortable and disciplined school is a school where school residents are free from fear, conducive to learning and positive relationships between school members. Schools that are safe, comfortable, and disciplined provide a clean and safe physical environment (buildings, classrooms, courtyards). In addition to aspects of physical security, comfort or the so-called school climate, namely concerning the atmosphere, feelings, the overall environment socially and emotionally the school must also be created positively.

\section{CONCLUSION}

Every element or member of an educational institution from various levels (elementary, junior and senior high) does not want violent conflict, wants a very conducive and peaceful atmosphere in order to create a cool learning atmosphere. but it was not created entirely in every educational institution, because there were still several aspects, firstly the mental / psychological state of students in terms of psychological development was still relatively immature or mature, students were still in the process of searching for identity (existence) so that they could be recognized by the environment in which they were. Second, the lack of knowledge about typologies of conflict and other forms of violence that appear in educational institutions / schools in everyday life. As for some typologies of conflict:
a. Without conflict
b. Surface conflict
c. Open conflict
d. Latent conflict 
Findings about violence in educational institutions can be divided into two. First is direct violence. Second, cultural violence. After knowing the variants of typology of conflict and violence in schools, the preventive steps that can be taken, first to socialize the types of sanctions for the perpetrators of violence in the environment of the second educational institution, design and implement a polite school system, do not make the school a shadow that continues to be a ghost frightening for students / students.

\section{REFERENCES}

[1] T. Lambang, "Development as development. Indonesian Torch Foundation", Jakarta, 2007.

[2] Laws of the republic Indonesia Number 20 of 2003 About National education system

[3] P2TP2 Team, "Jakarta Province. Pres Release of Sampang Police Station related to the chronology of the preservation of the teacher of SMAN 1 Torjun by his students", Author Code:KOMPAS.com/Taufiqurrahman.

03/02/2018, 2007.

[4] UNICEF dan Departemen Pendidikan Nasional RI, "Pedoman Pelatihan untuk Guru tentang Pencegahan Kekerasan terhadap Anak di Sekolah", Jakarta, 2006.

[5] W. Charles \& J. Galtung, "Handbook of Peace and Conflict Studies", New York, Routledge, 2007.

[6] S. Fisher, et al., "Manage conflicts. British Council", Jakarta, 2000.

[7] Data and information center for child protection. Indonesian children protection commission, 2018. Data and information center of the ministry of health of the Republic of Indonesia, 2018.

[8] J. Galtung, "Peace by Peaceful Means, Peace and Conflict, Development and Civilization", Oslo, PRIO (International Peace Research Institute, 1996.

[9] K. J. Pandori, "Adolescents Perceptions of Victims and Perpetrators of Cyberbullying", Thesis: University of Western Ontario, 2013.

[10] A. I. Budiarti, "The effect of interaction in friends group on students cyberbulliying behavior", Journal of thought sociology, Vol.3 No.1, 2016.
[11] Cyberbullying Behavior, Journal of Thought Sociology Vol. 3 No. 1.

[12] Law of the Republic of Indonesia Number 23 of 2002 concerning Child Protection

[13] C. Webel, \& J. Galtung, "Handbook of Peace and Conflict Studies", New York: Routledge, 2007. 